\title{
Integration of building construction courses in the architecture education programme
}

\author{
Ebru Alakavuk ${ }^{1 \mathrm{a}}$ \\ ${ }^{1}$ Yaşar Unıversity,Selçuk Yaşar Campus, Üniversite Street, Ağaçlı Yol No:37-39 Bornova,Izmır \\ 35100, Turkey
}

\begin{abstract}
The curriculum of architecture education programme is very important in respect to knowing that every course is related to each other. Design courses of curriculum are the combination of technical, theoretical and expression based courses. Building construction courses are technical courses of architecture department programme. As construction courses are the ones that give knowledge about structural systems, materials, structural stability etc. it has a fatal importance in the architecture education programme. The problem is how to integrate construction courses to architecture curriculum and to design studios. In this paper, a method of integration of construction course into design studio with a case study will be discussed. The aim of this paper is to create a reading through experience and practices on integrating construction courses into design studio.
\end{abstract}

Keywords: Architectural education; building construction courses; undergraduate education.

\section{Introduction}

Throughout the centuries, there has been a desire among the researchers to identify architecture as technology, craft, science or art. In fact, architecture is a combination of these four. All these characteristics are correlated to each other within the scope of architectural education and a student should learn how to deal with all of these factors. In this sense, architecture is a multidisciplinary, multi-skilled, multidimensional and multimedia practice and it is a self-sufficient profession that behaves as it already possesses all the knowledge that it needs, [1].

Architectural education, as one of the distinctive branches of education, requires the development of creative capabilities. The primary concern of architects is to produce three dimensional space and form to accommodate related human activities. Like other types of education, architectural education conveys, conserves, and transmits the values of the profession and society at large. Since humane environments are created in a field of tension

\footnotetext{
${ }^{a}$ Corresponding author: ebru.alakavuk@yasar.edu.tr
} 
between reason, emotion and intuition, architectural pedagogy should be viewed as training toward the manifestation of the ability to conceptualize, coordinate, and execute the idea of building rooted in humane tradition.

In 2004, UNESCO/UIA Charter for Architectural Education indicated that architectural education should involve the acquisition of the capabilities of understanding technical knowledge of structure, materials and construction. Consequently, understanding of the processes of technical design and the integration of structure, construction technologies and services systems into a functionally effective whole, [2].

As Uluoğlu, [3] states that architectural education curriculum is composed of four main types of courses:

1. Fundamental courses; are theoretical courses

2. Technology based courses; are construction, structure, material courses

3. Expression based courses; technical drawing courses

4. Design studio courses

In the light of the European policies for Higher Education, Bologna Declaration in 1999, the consideration of architectural curricula shows that, when the relationship of architectural design and construction is considered, the construction is a necessary and inseparable part of the design process. Consequently, this relationship of architectural design and construction must be reflected in the curriculum of architectural education in a way that the students of architecture can understand this relation very well in order to comprehend the contact of these two parallel and related subjects. Then, they can apply their knowledge of construction to project design courses properly, [4].

The teaching of technical disciplines to architecture students has long been recognized to be a difficult exercise. For many students of architecture, study of structures, for example, is peripheral to their main task of 'architectural design'. Yet it is generally agreed that an understanding of the structure can enrich and enhance an architectural design process. In order to achieve the maximum benefit, the technical subjects must be integrated with the design, [5].

In architecture department curriculum lots of technical courses can be find. These are building construction, building materials, project management, statics of the materials courses etc. Briefly we can say that technical courses are practice based ones. So these courses help the architects to understand "why buildings stand up?". By the help of these courses architects can command on the structural system of the building. Although load calculations of the structural system of a building is done by a civil engineer, architect also must know how to locate the structural elements on the design.

In building construction courses' syllabus we can see building construction systems, building materials, building elements, detailing of construction systems etc. All of these topics concern with the real life practice. If we look closer to these topics, we can firstly talk about the building construction systems. In architecture department undergraduate programme masonry systems, reinforced concrete systems, timber systems precast systems and steel construction systems are thought to the students. Every system has its own dynamics and load carrier system. So in the building construction courses each of these systems must be thought deeply from foundation systems till roof systems. After the knowledge about construction systems is given, students are ready to learn details. Following building construction courses give knowledge about window, door systems, roof details, wall covering details, floor covering details, suspended ceiling systems, wet places, furniture details, cabinet details etc.

As it can be seen above lots of knowledge about the construction systems are given to the students all through their education. The problem is how to integrate these construction knowledge to design process. Students used to not think about the structural systems and 
details of the building in the design studio. In this research a method of coordinating design studio with construction courses is introduced.

\section{Integration of construction courses to design studio}

Firstly it will be better to talk about the integrated design studio in detail. The design studio took place in 2013 in the third year of undergraduate architecture students. The subject given to the students "Integral Design Studio III" is "Redefining urban public spaces by Housing within the Context of Earthquake'. This course introduces students to earthquake architecture with special emphasis placed on the implementation of architectural decisions, creations and ideas to accommodate for earthquake. The unit will aim to heighten student's awareness of designing complex geometrical designs in buildings by providing an overview of the structural principles. The unit attempts to explore key approaches to the principles of seismic design, including strategies for designing earthquake resistant buildings to ensure the health, safety, and security of the occupants. Further goals of the unit are to develop:

Conceptual thinking of the architecture and the cultivation of design ideas.

Ability to create and develop a method for design. Relate public, semi-public and private spaces in architectural design program.

Ability to project spatial organization of varying spaces in a medium-density urban area.

Ability to analyze how earthquake architecture could influence the design process.

The project area is located in an old industrial area covering the neighborhoods of Ege University and Yasar University campus in Izmir, Turkey. In addition to pitched terrain of the site; nearby multiple, complex and nested building patterns and social life are very important design inputs for this project. Thus, students are expected to determine the optimum orientation and layout for 3 different kinds of dwelling units for different user profiles. Residential spaces will be $4000 \mathrm{~m} 2$ and social spaces (community or retail spaces) will be $500 \mathrm{~m} 2$. Furthermore, not only organizing the building mass, but also the related open spaces in the neighborhood should be considered in benefits of public usages. In addition to the contribution of environmental data (which is either urban or recreational) to the architectural design, it's expected that architectural design should accommodate or make a positive transformation on environment. All students are expected to consider the organization of varying functions, and relations between spatial organization and structure. They are also expected to be aware of and discuss the semantic paradigms in the architecture. Students are expected to be aware of key approaches to the principles of seismic design, various structural design systems with special emphasis on earthquake resistance and integrate these design systems with their previous design while taking advantage of digital technologies.

Integral Design Studio consists of two successive stages; design part, earthquake and architectural design part. Starting with the 'Design Part', students are expected to gain research and conceptual development skills on the given design context. This stage will be closed by the completion of the architectural design proposals on Week 13. In the architectural design stage of the design studio firstly students make site analysis and make site model. See Fig. 1. 

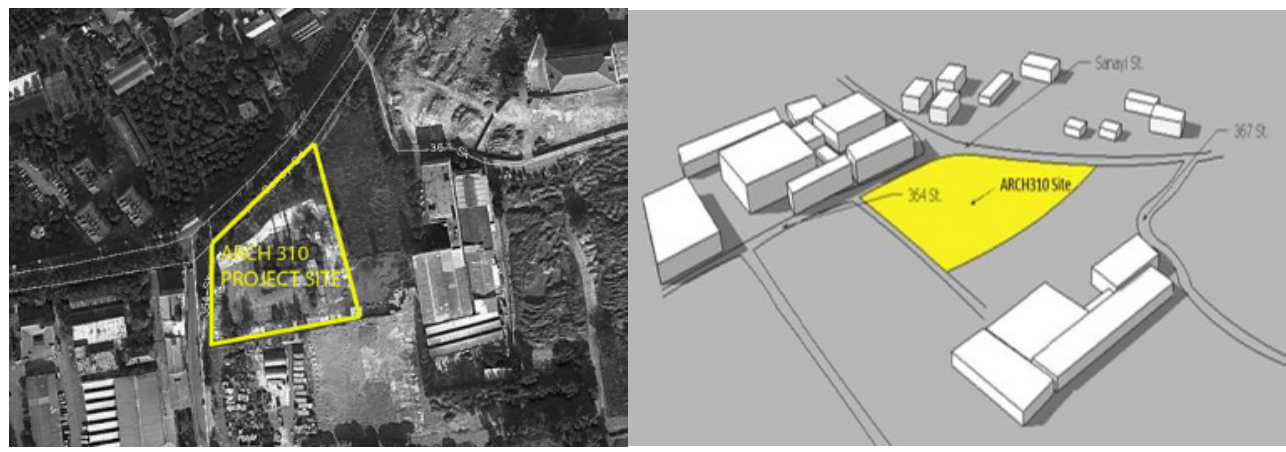

Fig. 1. Design studio project site

Secondly students work on spatial organization and site relations and also context of the design. See Fig. 2.
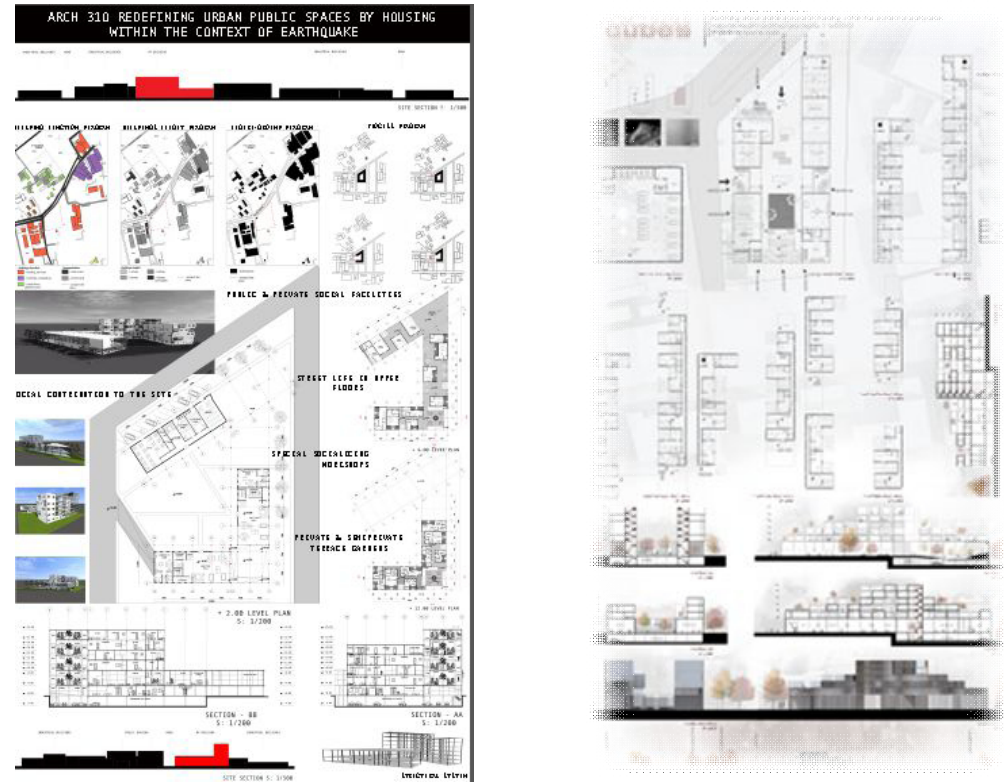

Fig. 2. Examples of conceptual sketches of students

The second stage which continues during the next four weeks is the 'Earthquake and Architectural Design'. In this part, students are expected to be aware of key approaches to the principles of seismic design, various structural design systems with special emphasis on earthquake resistance and integrate these design systems with their previous design while 
taking advantage of digital technologies. In this design studio students used ideCAD simulation programme for testing the structural stability of their design.

When the building model is transferred from ideCAD Architectural, the construction components are already defined. After the data model has been transferred to the ideCAD structural, reinforced-concrete design of columns, beams and slabs can be carried out, cross-section proposals optimized, and reliable and economical cross-sections specified. See Fig. 3.
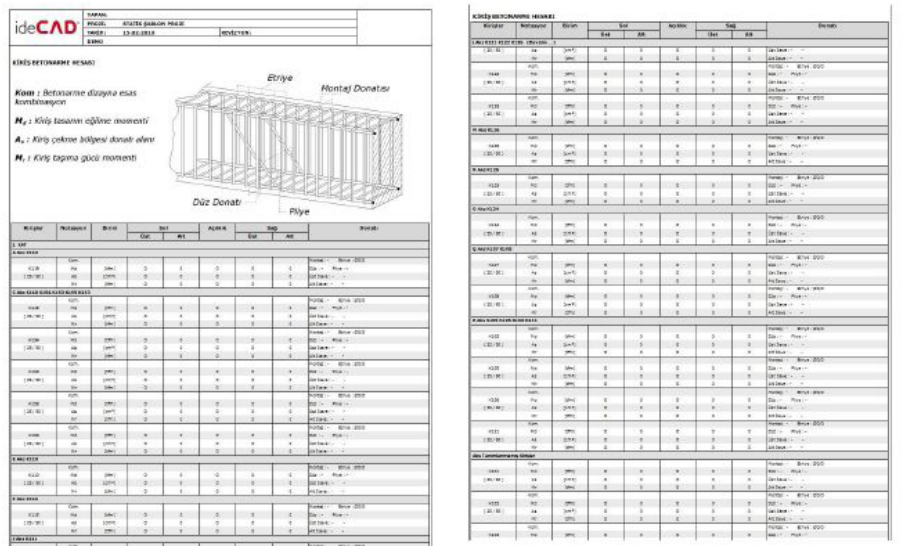

Fig. 3. An example of result of structure simulation analysis

By using ideCAD simulation programme students can test whether the located structural system can carry the loads or not. And also the dimension of structural system can be tested. If the dimension, size of the section is not suitable then students can see the deterioration of columns and beams. See Fig. 4. After that according to the results of the simulation programme, the dimensions of the structural system can be changed accordingly and till a range of forces (for example; earthquake) building can stand up.

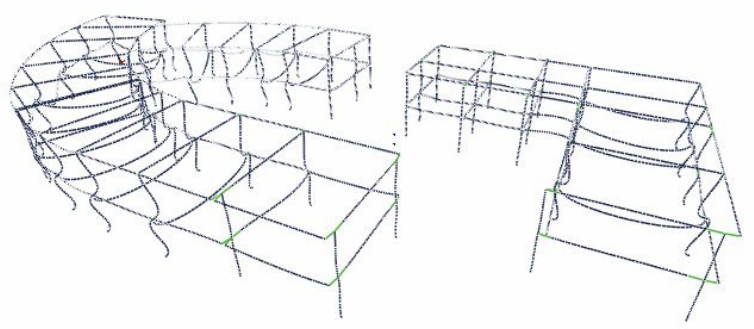

Fig. 4. The deterioration of columns and beams

\section{Conclusion}

Construction courses have a fatal importance in the architecture curriculum since these courses are due to the professional life. Students must learn how to integrate construction principles to their design projects. Design studio is the course where this integration can be done. In this article an experimental approach to integral design studio about integration of 
construction courses is explained. This exemplified applications and experiences are based on the author's practices in undergraduate design studio instruction. In this design studio students learned how to examine the dimensions of structural system and re-value the dimensions again according to the results of the simulation programme. So from that time on students have known that structure system must thought from the beginning of the design process. As a result; students awareness about combining design and construction is increased by integration of construction courses into design studio.

\section{References}

1. French, H., Architecture: A crash course. New York: WatsonGuptill Pub., (1998).

2. Uzunoğlu, S. S. \& Quriesh A., A method of adapting construction education in architectural design education. Procedia - Social and Behavioral Sciences 51.546 552, (2012).

3. Uluoğlu, B., Mimari tasarım eğitimi: tasarım bilgisi bağlamında stüdyo eleştirileri. $\mathrm{Ph}$ D. Thesis. İstanbul: İstanbul Teknik Üniversitesi, (1990).

4. Voyatzaki, M., Construction history in the architectural curricula in Europe, Second International Congress on Construction History, Queens' College, Cambridge University; 29/03-02/04/2006, (2006).

5. Banerjee, H.K. \& De Graaff, E., 'Problem-based learning in architecture: problems of integration of technical disciplines', European Journal of Engineering Education 21(2), 185-195, (1996).

6. Teymur, N., Architectural education: Issues in educational practice and policy. London: Question Press, (1992).

7. Ashraf, S., Skill- Based /knowledge based architecture pedagogies: an argument for creating human environments. In: 7TH intl conference on Humane Habitate-ICHH-05The international Association of Humane habitat ICHH. Rizvi College of Architecture,Mumbai, India, (2005). 